\title{
How Managers Use Information Systems for Strategy Implementation in Agritourism SMEs
}

\author{
Maria Kamariotou *(D) and Fotis Kitsios \\ Department of Applied Informatics, University of Macedonia, GR54636 Thessaloniki, Greece; kitsios@uom.gr \\ * Correspondence: mkamariotou@uom.edu.gr
}

Received: 1 June 2020; Accepted: 18 June 2020; Published: 20 June 2020

\begin{abstract}
Agritourism is long established and the interest in diversification of agricultural enterprises into tourism has increased. However, many challenges have emerged regarding the lack of appropriate skills, strategic planning, Information Systems (IS), as well as increased costs in production processes. In Greece, the contribution of agritourism to economic growth has increased in the last decade, but the relationship between the agricultural sector and agritourism is a reason for certain people having largely taken advantage from the development of tourism in a specific area. Greek businesses operating in the agritourism sector are seeking long-term sustainability. However, they lack strategic planning and effective use of IS. As the strategic implementation of Information Technology (IT) in Small Medium Enterprises (SMEs) in the agritourism sector is under-researched, this paper aims to investigate how the process of Strategic Information Systems Planning (SISP) affects the success of Greek SMEs in the agritourism industry. IS executives completed the survey and ANOVA analysis was used for data analysis. The findings of the paper indicate that IS executives do not focus on the analysis of the external environment and the evaluation of opportunities for IS development. In addition, the lack of formulation of the IT strategy creates inefficient and unsuccessful IT projects.
\end{abstract}

Keywords: agritourism; strategic information systems planning; small medium enterprises; IS strategy; success

\section{Introduction}

The interest in multifunctionality and diversification emerged through the severe criticisms, during the last three decades, addressing the capitalization, concentration, and specialization of agriculture as well as its integration into agribusiness chains, which in turn, shrink its synergies with other fields of activity and between different levels and actors [1]. In the agricultural sector, many changes have been made in production processes, information sources, as well as the usage of information due to the increase of technology and the development of computer networks. The spread of communication technologies has increased access to knowledge and sharing of information [2]. That is why innovation is an important factor for businesses operating in the agricultural sector and helps them grow, be sustainable, and be competitive $[1,3,4]$.

The agritourism sector is considered one of the most significant pillars of the EU economy. This sector contributes to both employment and the economy [1,5,6]. Many researchers have presented the multiple advantages of the development of various forms of tourism in rural areas. Moreover, tourism in rural areas, when being endogenously-owned and small scale is considered conducive to sustainable rural development. A significant challenge concerns the fact that entrepreneurs in this sector often lack appropriate skills they may be isolated from, without prior experience or training in tourism. Furthermore, other factors that prevent entrepreneurs from engagement with tourism related activities are age, the innovative character of the new activity, and the lack of sufficient capital [7]. 
In Greece in particular, agritourism's contribution to economic growth has increased over the last decade [7]. While Greek agricultural companies concentrate on long-term sustainability, the lack of IT strategy produces ineffective and unsuccessful Information Systems (IS) projects [7-11]. Significant issues relate to the lack of appropriate expertise, lack of financial resources and strategic planning for food businesses. In addition, costs are raised in the production processes and the usage of IS inefficiently $[12,13]$.

Despite the importance of the process of Strategic Information Systems Planning (SISP), the strategic implementation of Information Technology (IT) is not sufficiently studied in the international agritourism literature and especially Small Medium Enterprises (SMEs) in the tourism sector are under-researched. As SMEs concentrate on growing innovation and growth, managers are trying to balance their business strategy with IT to keep companies competitive in the unpredictable environment that they are currently experiencing. However, limited strategic planning, the lack of structured processes in organizations, as well as the wasteful usage of IS increase the inability of managers to align business with IT strategies and leads to a long term decrease [14-17]. Firm performance can be enhanced if managers in SMEs use formal processes during strategic management and information handling. As IT investments increase organizational performance and enable managers to align the business approach with firm performance, alignment is a significant issue for executives [18-21].

This study aims to examine the relationship between SISP phases and success in Greek SMEs in the agritourism industry. Data for the study were obtained from IS directors in Greek SMEs in the agritourism industry. For the analysis of SISP process and success variables, ANOVA was used in order to indicate which phases of the SISP process significantly contributes to SISP success.

\section{Literature Review and Hypotheses}

\subsection{Strategic Information Systems Planning Phases}

SISP has been described by academics and professionals as an integrated process that integrates different phases. Such steps reflect the planning of the process's individual activities. Based on the existing literature [22-33], the SISP process consists of five phases and previous researchers have used them in order to measure their impact on the success of the process. Strategic awareness, which is the starting phase, involves activities related to the identification of important planning problems, priorities, goals, selection of the IS team members, and the willingness of top-level managers to be engaged in the process. The key tasks of the second phase of the SISP process are the study of existing business structures, organizational processes, and Information Systems in addition to the study of the external and internal IT environment. IT managers set important goals, opportunities for change and high-level IT strategies during the third stage of the SISP process. Strategy formulation is the fourth phase of the SISP process. The main activities included in this phase are the identification of new business processes, new IT architectures in order to achieve IT goals, specific new IT projects, and priorities for these projects. Finally, the last phase of the process, named strategy implementation planning, includes the identification of change management approaches and action plans. Furthermore, in this phase IT managers evaluate the output of the process and if the goals of the first phase have been achieved [22-33].

The results of the existing literature show that IT managers concentrate their efforts on strategy conception and strategy execution. Furthermore, IS executives avoid investing time on the first and second phase of the process. Thus, the output of the implementation of SISP process is the development of ineffective and unsuccessful IT plans that do not achieve businesses' goals. Senior managers have a small budget available to build IS, so they do not focus their efforts on identifying strategic objectives such as how IS will improve the profitability of the company. They only focus on the minimization of the project implementation time and cost. The focus of executives only on the implementation of the process has negative results because it may lead in less time to the execution of the process of SISP, but the strategic objectives of the company are not aligned with the objectives of IT [24-28,31,32,34-38]. 
In strategic awareness, managers gain appropriate knowledge about competitors, customers, resources, and regulations in order to identify IT goals. Furthermore, IS executives have to organize the planning team and give specific responsibilities to all members for the development of IS projects. However, top managers should commit to the process of SISP in order to increase organizational confidence and provide continual financial support for IT projects. Hence:

H1. Strategic awareness positively influences SISP success in the agritourism industry.

IS executives should pay focus on the execution of situational analysis with a view to executing policy formulation and implementation preparation with greater agility in the future. Managers will evaluate existing business and organizational structures, current IS, as well as the company's internal and external business environment. The situation analysis of such analytical findings will help them match IT policy with business strategy. In addition, the outcomes of a situation review will greatly increase the planning performance and raise the time and expense of the process. Analyzing the environment, managers can define significant IT goals and opportunities in order to improve and evaluate IT projects. They can also identify high-level IT strategies in order to develop effective IS projects [30,39-42].

H2. Situation analysis positively influences SISP success in the agritourism industry.

Academics who had researched the impact of the process of SISP on success have concluded that IT managers have paid attention to the strategic conception phase. In strategy conception, IS executives focus on evaluating opportunities in order to provide more realistic alternative scenarios. Organizations should be able to align IT with company priorities by their awareness, hereby allowing managers to provide some viable scenarios and choices to lead to produce better results when carrying out the project $[22,24,27,31,32]$. This phase is significant for planners in order to identify suitable alternative strategies. Despite the significance of this phase, IS executives do not subsequently focus their efforts on the achievement of IT goals and IT projects do not positively affect SISP success. Hence:

\section{H3. Strategy conception positively influences SISP success in the agritourism industry.}

The most common issues that have arisen during the execution of the process of SISP are the limited top management engagement to the process and the failure to establish successful strategies to implement IS. If managers do not support the development of IT projects, members of the development team will not be committed to the plans and will face problems in executing the IS strategy. Therefore, it is important for executives to set priorities that would result in being better able to implement their IS strategy and achieve their goals. The results of the existing literature show that IS executives tend to pay attention to the execution of IS strategy. This happens because they consider strategy implementation as a difficult process. When managers concentrate on the implementation of the process, they may achieve shorter SISP horizons, but the strategic goals cannot be met. Executives do not focus on what strategic objectives really concern and how they can increase value to the business because they invest time on the horizon of the project and on minimizing its cost due to a limited IT budget $[23,24,27,31,33]$. Hence:

H4. Strategy formulation positively influences SISP success in the agritourism industry.

H5. Strategy implementation positively influences SISP success in the agritourism industry.

The phases of SISP process and their activities are presented in Table 1. 
Table 1. Strategic Information Systems Planning (SISP) phases and activities.

\begin{tabular}{lllll}
\hline 1st Phase & 2nd Phase & 3rd Phase & 4th Phase & 5th Phase \\
\hline $\begin{array}{l}\text { Determine key } \\
\text { planning issues }\end{array}$ & $\begin{array}{l}\text { Analyze current business } \\
\text { systems }\end{array}$ & $\begin{array}{l}\text { Identify major IT } \\
\text { objectives }\end{array}$ & $\begin{array}{l}\text { Identify new } \\
\text { business processes }\end{array}$ & $\begin{array}{l}\text { Define change } \\
\text { management } \\
\text { approaches }\end{array}$ \\
\hline $\begin{array}{l}\text { Determine } \\
\text { planning objectives }\end{array}$ & $\begin{array}{l}\text { Analyze current } \\
\text { organizational systems }\end{array}$ & $\begin{array}{l}\text { Identify } \\
\text { opportunities for } \\
\text { improvement }\end{array}$ & $\begin{array}{l}\text { Identify new IT } \\
\text { architectures }\end{array}$ & Define action plans \\
\hline $\begin{array}{l}\text { Organize the } \\
\text { planning team }\end{array}$ & $\begin{array}{l}\text { Analyze current } \\
\text { Information Systems }\end{array}$ & $\begin{array}{l}\text { Evaluate } \\
\text { opportunities for } \\
\text { improvement }\end{array}$ & $\begin{array}{l}\text { Identify specific } \\
\text { new projects }\end{array}$ & $\begin{array}{l}\text { Evaluate action } \\
\text { plans }\end{array}$ \\
\hline $\begin{array}{l}\text { Obtain top } \\
\text { management } \\
\text { commitment }\end{array}$ & $\begin{array}{l}\text { Analyze the current } \\
\text { external business } \\
\text { environment }\end{array}$ & $\begin{array}{l}\text { Identify high level } \\
\text { IT strategies }\end{array}$ & $\begin{array}{l}\text { Identify priorities } \\
\text { for new projects }\end{array}$ & $\begin{array}{l}\text { Define follow-up } \\
\text { and control } \\
\text { procedures }\end{array}$ \\
\hline & $\begin{array}{l}\text { Analyze the current } \\
\text { external IT environment }\end{array}$ & & & \\
\hline
\end{tabular}

\subsection{Strategic Information Systems Planning Success}

According to the existing literature, SISP success can be defined as "the level to which the aims of SISP process have been realized" [37]. Alignment, analysis, collaboration, and capabilities are the four dimensions of the concept of SISP success.

The dimensions of SISP success and their items are presented in Table 2.

Table 2. Success dimensions and variables.

\begin{tabular}{|c|c|c|c|}
\hline 1st Dimension & 2nd Dimension & 3rd Dimension & 4th Dimension \\
\hline $\begin{array}{l}\text { Maintaining a mutual } \\
\text { understanding with top } \\
\text { management on the role of } \\
\text { Information Systems (IS) in } \\
\text { supporting strategy }\end{array}$ & $\begin{array}{l}\text { Identifying opportunities for } \\
\text { internal improvement in } \\
\text { business processes through IT }\end{array}$ & $\begin{array}{l}\text { Developing clear guidelines of } \\
\text { managerial responsibility for } \\
\text { plan implementation }\end{array}$ & $\begin{array}{l}\text { Ability to identify key } \\
\text { problem areas }\end{array}$ \\
\hline $\begin{array}{l}\text { Understanding the strategic } \\
\text { priorities of top management }\end{array}$ & $\begin{array}{l}\text { Maintaining an understanding } \\
\text { of changing organizational } \\
\text { processes and procedures }\end{array}$ & $\begin{array}{l}\text { Identifying and resolving } \\
\text { potential sources of resistance } \\
\text { to IS plans }\end{array}$ & $\begin{array}{l}\text { Ability to anticipate } \\
\text { surprises and crises }\end{array}$ \\
\hline $\begin{array}{l}\text { Identifying IT-related } \\
\text { opportunities to support the } \\
\text { strategic direction of the firm }\end{array}$ & $\begin{array}{l}\text { Generating new ideas to } \\
\text { reengineer business processes } \\
\text { through IT }\end{array}$ & $\begin{array}{l}\text { Maintaining open lines of } \\
\text { communication with other } \\
\text { departments }\end{array}$ & $\begin{array}{l}\text { Flexibility to adapt to } \\
\text { unanticipated changes }\end{array}$ \\
\hline $\begin{array}{l}\text { Aligning IS strategies with } \\
\text { the strategic plan of } \\
\text { the organization }\end{array}$ & $\begin{array}{l}\text { Understanding the } \\
\text { information needs } \\
\text { through subunits }\end{array}$ & $\begin{array}{l}\text { Coordinating the development } \\
\text { efforts of various } \\
\text { organizational subunits }\end{array}$ & $\begin{array}{l}\text { Ability to gain } \\
\text { cooperation among user } \\
\text { groups for IS plans }\end{array}$ \\
\hline $\begin{array}{l}\text { Adapting the } \\
\text { goals/objectives of IS to } \\
\text { changing goals/objectives of } \\
\text { the organization }\end{array}$ & $\begin{array}{l}\text { Understanding the dispersion } \\
\text { of data, applications, and other } \\
\text { technologies throughout } \\
\text { the firm }\end{array}$ & $\begin{array}{l}\text { Establishing a uniform basis } \\
\text { for prioritizing projects }\end{array}$ & \\
\hline $\begin{array}{l}\text { Educating top management } \\
\text { on the importance of IT }\end{array}$ & $\begin{array}{l}\text { Development of a "blueprint" } \\
\text { which structures } \\
\text { organizational processes }\end{array}$ & $\begin{array}{l}\text { Achieving a general level of } \\
\text { agreement regarding the } \\
\text { risks/tradeoffs among system } \\
\text { projects }\end{array}$ & \\
\hline $\begin{array}{l}\text { Adapting technology to } \\
\text { strategic change }\end{array}$ & $\begin{array}{l}\text { Improved understanding of } \\
\text { how the organization } \\
\text { actually operates }\end{array}$ & $\begin{array}{l}\text { Avoiding the overlapping } \\
\text { development of major systems }\end{array}$ & \\
\hline $\begin{array}{l}\text { Assessing the strategic } \\
\text { importance of } \\
\text { emerging technologies }\end{array}$ & $\begin{array}{l}\text { Monitoring of internal } \\
\text { business needs and the } \\
\text { capability of IS to meet } \\
\text { those needs }\end{array}$ & & \\
\hline
\end{tabular}

The first aspect concerns executives' perception of the use of IS to help business strategy and discover opportunities that will benefit the company's strategic path. Other variables included 
in this dimension are the agreement of IT strategy with business strategy, the training of top management in order to understand the significance of IT, and its adaption in the strategic change of the organization $[24,26,31-33,43-45]$. The second dimension refers to the birth of new ideas regarding the reorganization of business processes with the support of IT [46]. Currently, the comprehension of the information needs to be across various subunits, exchange of data, dispersion applications, and other technology within the company to build a blueprint to develop the organization, considered each to be equally very important issues. All of these processes allow the managers to know how the organizations operate. Thus, IT executives can assess internal business needs as well as the required technical abilities to meet those needs [24,26,31-33,44,45].

The third dimension consists of variables such as the capability of executives to come up with clear guidelines, the managerial tasks for effective implementation of IS plans, and the identification of potential causes of opposition to IT projects. Other variables included in this dimension are the willingness of managers to encourage open lines of communication with other sections of the company to arrive at a general level of adaptation among all the risks/tradeoffs between system projects and dissuade the implementation of organizational growth. The fourth dimension contains many capabilities regarding the identification of key problem areas, dealing with surprises and crises, flexibility adjusting to expected changes, as well as strengthening collaboration between user groups to implement IS [24,26,31-33,44,45].

\section{Methodology}

For the IS executives, a field survey was used. A five-point Likert-scales instrument was used to initiate two themes: the phases of the SISP process and its success. Regarding the first construct, it determined the degree to which agritourism SMEs conducted the five phases of the process of SISP and their activities. The following variables were used to measure the success constructs; alignment, analysis, cooperation, and capabilities. The instrument was hinged on the existing literature that studied the impact of the process of SISP on success [14,23,31,32].

Four managers were accepted to complete a pilot survey in order to provide feedback for the content, length, and general appearance of the instrument. The Icap list was used in order to select the sample of the survey consisting of IT managers in Greek SMEs that are involved in the agritourism sector [31,32]. The Icap list comprises the total number of SMEs per sector in Greece. The Icap list was used to communicate with the IT managers in the agritourism sector for data collection. SMEs must meet the following conditions: The number of staff must be between $20-50$ and the income should not exceed 50 million euros. The sample for the survey was SMEs with contact details. The instrument was assigned to 296 IT managers in Thessaloniki and Athens and only 61 completed the survey. Data were analyzed using ANOVA.

\section{Results}

The internal reliability determined by the Cronbach's alpha, ranged from 0.746 to 0.918 , thus exceeding the marginally required level of 0.70 [31]. The Cronbach's alpha coefficient values for the variables is presented in Table 3.

Table 3. Reliability analysis of the questionnaire items.

\begin{tabular}{ccc}
\hline Variables & No. of Items & Cronbach a \\
\hline 1st phase & 4 & 0.753 \\
2nd phase & 5 & 0.746 \\
3rd phase & 4 & 0.812 \\
4th phase & 4 & 0.784 \\
5th phase & 4 & 0.789 \\
Success & 27 & 0.918 \\
\hline
\end{tabular}


The outcomes of Pearson's correlation analysis done to ascertain the level and type (direct or inverse) of relationship amongst the variables are presented in Table 4.

Table 4. Correlation matrix.

\begin{tabular}{ccccccc}
\hline & 1st Phase & 2nd Phase & 3rd Phase & 4th Phase & 5th Phase & $\begin{array}{c}\text { Success } \\
\text { (SU) }\end{array}$ \\
\hline 1st phase & 1 & 0.716 & 0.772 & 0.701 & 0.746 & 0.784 \\
2nd phase & 0.716 & 1 & 0.695 & 0.755 & 0.753 & 0.778 \\
3rd phase & 0.772 & 0.695 & 1 & 0.722 & 0.751 & 0.782 \\
4th phase & 0.701 & 0.755 & 0.722 & 1 & 0.726 & 0.769 \\
5th phase & 0.746 & 0.753 & 0.751 & 0.726 & 1 & 0.791 \\
\hline
\end{tabular}

From the normal P-P and scatter plots (Figure 1), the data are usually distributed (all residuals cluster around the 'line') and conform with the assumptions of homogeneity of variance (homo-scedasticity) and linearity. The residual errors are evenly spread and not linked to the predicted value, thereby suggesting that the correlation is linear, and the variance of $\mathrm{y}$ is the same among all values of $x$, which supports the homoscedasticity assumption [8]. Z-score was used to evaluate the univariate outliers and all values were within the acceptable range. Mahalanobis and Cook's distances were used to evaluate the multivariate outliers. No influential outliers were identified. Variance inflation factors (VIFs) were used to evaluate multicollinearity.
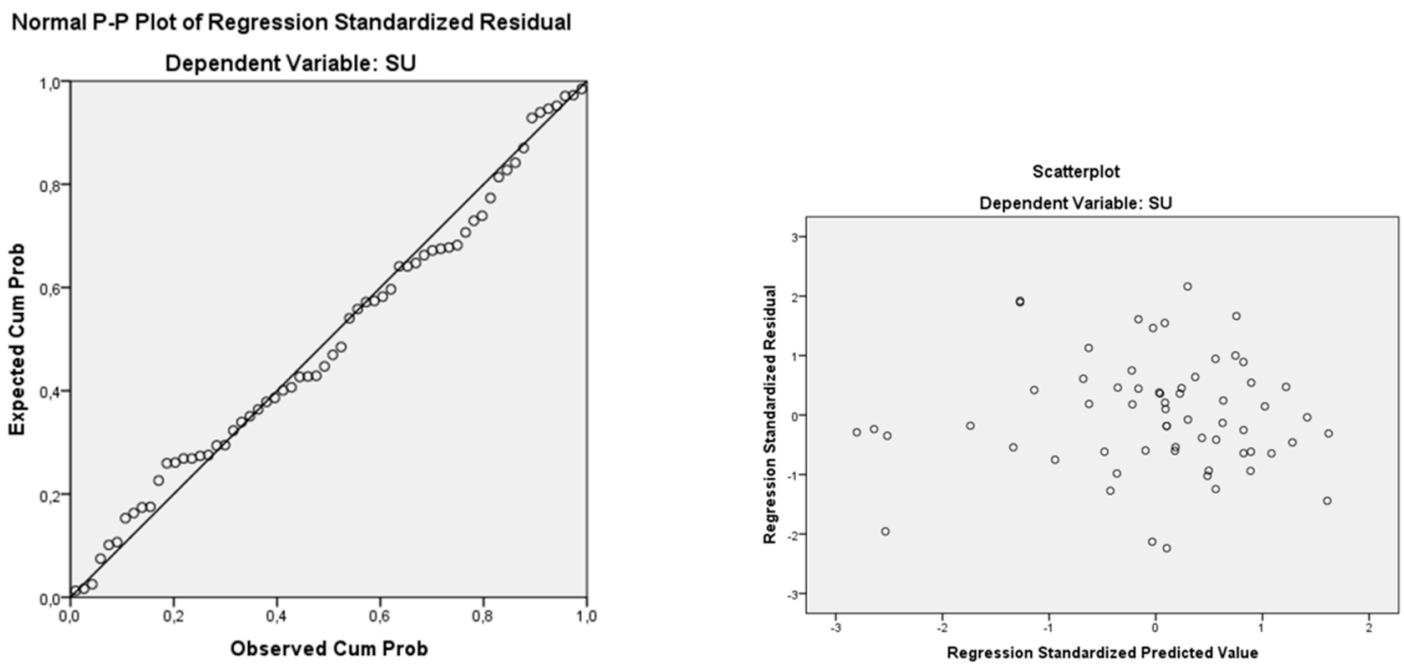

Figure 1. Standard P-P plot of the regression standardized residual and a residual scatter plot.

Table 5 shows the summary indicators of $R, R^{2}$, and adjusted $R^{2}$, along with the Durbin-Watson indicator and the standard deviation error of the regression. According to the $\mathrm{R}^{2}$ and adjusted $\mathrm{R}^{2}$ values of 0.775 and 0.755 , approximately $75 \%$ of the variance in success is explained by the explanatory variables. Consequently, the regression model predicts success better since the explanatory power of the regression exceeds $50 \%$. The results of the ANOVA regression in Table 6 also support the satisfactory prediction performance of the regression model. The F statistic is 35.587 with 61 degrees of freedom ( 5 from the regression and 56 from residuals), and the whole regression is significant at the 0.000 level.

Table 5. Model summary indicators.

\begin{tabular}{ccccc}
\hline $\mathbf{R}$ & $\mathbf{R}^{\mathbf{2}}$ & Adjusted $\mathbf{R}^{\mathbf{2}}$ & Estimate Standard Error & Durbin-Watson \\
\hline 0.880 & 0.775 & 0.755 & 0.367 & 1.793 \\
\hline
\end{tabular}


Table 6. ANOVA statistics of regression.

\begin{tabular}{ccccccc}
\hline Model & & Sum of Square & Df & Mean Square & $\boldsymbol{F}$ & Sig. \\
\hline \multirow{2}{*}{1} & Regression & 26.063 & 5 & 5.213 & 35.587 & 0.000 \\
& Residual & 7.565 & 56 & 0.135 & & \\
& Total & 33.628 & 61 & & & \\
\hline
\end{tabular}

Table 7 shows the regression coefficients and the results of hypothesis testing. The path coefficient between the first phase of the process of SISP and its success was positive, but not statistically significant ( $\beta=0.208, p>0.05$ ). Therefore, $\mathrm{H} 1$ was not supported. There was a positive relationship between the second phase of the process of SISP and its success $(\beta=0.202, p>0.05)$, but not statistically significant. Therefore, $\mathrm{H} 2$ was not supported. There was a positive relationship between the third phase of the process of SISP and its success $(\beta=0.197, p>0.05)$, but not statistically significant. Thus, H3 was not supported. The path coefficient between the fourth phase of the process of SISP and its success was positive, but not significant statistically $(\beta=0.180, p>0.05)$. Therefore, H4 was not supported. There was a positive relationship between the fifth phase of the process of SISP and its success $(\beta=0.206, p>0.05)$, but statistically not significant. Thus, H5 was not supported.

Table 7. Regression analysis between independent variables. (1st phase, 2 nd phase, 3 rd phase, 4 th phase, 5th phase) and dependent variable (Success). ${ }^{*} p<0.05,{ }^{* *} p<0.01,{ }^{* * *} p<0.001$.

\begin{tabular}{cccc}
\hline Model & $\boldsymbol{\beta}$ & $\boldsymbol{t}$-Value & VIF \\
\hline 1st phase & 0.208 & 1.840 & 3.175 \\
2nd phase & 0.202 & 1.808 & 3.107 \\
3rd phase & 0.197 & 1.728 & 3.231 \\
4th phase & 0.180 & 1.645 & 2.980 \\
5th phase & 0.206 & 1.783 & 3.308 \\
\hline
\end{tabular}

The findings of this article prove that IS executives are not concentrating their attention on assessing the internal and external business environment. This outcome is significant since it confirms that managers in SMEs in the agritourism sector are not investing in Information Technology and that these companies cannot be competitive. In addition, an important outcome is that managers do not make efforts to organize the planning team and provide guidance on the implementation of IS projects. Another important process is the selection of employees who will be the members of the development team. This process is significant because team members should have cooperation and IT skills as well as motivation to develop effective IT projects. The projects that could not help a business to achieve their goals have been implemented by employees whose managers did not assist the planning team during the development of those revenues. Furthermore, these projects do not meet organizational processes and do not contribute to business development. The absence of management assistance from executives and the absence of clear guidelines on the execution of IT projects can negatively contribute to this output. These outcomes substantiate the rejection of the H1.

An important outcome is also the lack of understanding of executives about the value of IT strategy and the formulation of priorities for dealing with risks and crises. IT managers are unable to recognize areas because it is difficult to understand business processes. IT projects that are built on the present business processes are developed by team members. So, the IS plans are unable to achieve IT goals. This result reflects undesirable impacts SMEs are experiencing because of the lack of strategic planning.

Researchers in their studies pointed out that IS managers focus their energies on strategy creation and strategy implementation, ignoring the significance of strategic recognition and situation analysis. IS plans implemented are therefore inadequate, inefficient, and do not meet IT goals [14,25,28,47-49]. These findings confirm the rejection of $\mathrm{H} 4$ and $\mathrm{H} 5$. Also, managers focus only on the minimization of project implementation time and cost. Managers pay attention only to the implementation of the 
SISP and the company's strategic priorities are not in line with the IT goals, which in turn have a disadvantage for the company $[14,50]$.

All hypotheses were not supported because managers in this sector often lack appropriate skills, they may be isolated, without prior experience or training in tourism. Furthermore, other factors that prevent entrepreneurs from engagement with tourism-related activities are age, the innovative character of the new activity, and the lack of sufficient capital. Thus, managers face difficulties in understanding the significance of IS implementation and as a result in formulating, implementing, and evaluating strategic plans. Therefore, they ignore the analysis of the business environment, they do not support IT projects and due to limited resources and lack of innovation culture, they do not invest in IS.

\section{Conclusions}

This paper examined how the process of SISP affects the success in Greek SMEs in the agritourism industry. The outcomes of this paper suggest that IT managers are not concentrating their attention on the analysis of the internal and external business environment. A significant finding is also the lack of awareness by managers about the importance of IT strategy and formulating goals to predict threats. IS executives cannot find problem areas because company's processes are not revamped. In addition, administrators concentrate primarily on reducing the project's duration and lowering costs. The focus of managers only on process execution has negative effects as it can lead to shorter SISP horizons but not to match strategic objectives with IT ones.

Conclusively, this article has a twofold contribution. Firstly, concerning theoretical contribution, if IT executives understand these phases then they may focus their attention on achieving the goals of the organizations and maybe realize the importance of the planning procedure for their organization. IS executives should be aware of the five phases and must not neglect the individual responsibilities of each phase as this may stand as an obstacle to the company and prevent it from achieving its planned goals and increasing the profitability of the company. Secondly, the results help IT managers working in Greek SMEs in the agritourism industry and do not focus on implementing strategic planning in the growth of IS, but concentrate only on technical matters. Consequently, there is a need to recognize the importance of the process of SISP to draw up and execute IS strategy that will comply with business goals and expand the performance of SMEs in the agritourism industry.

A better understanding of the connection between business and IT strategy and organizational success is crucial over the years. To investigate what are the most important practices that lead to the creation of productive IT projects, researchers had to concentrate on the SISP process practices. Managers are required to pay more attention to day-to-day activities in order to achieve a greater extent of alignment and to understand the significance of formulating IS strategy. Potential researchers should therefore study alignment as a process involving activities that could lead to growing the connections between business strategy, IT, and efficiency across SMEs. Another avenue for further research is to investigate those responsible for decision making as well as the role they play in an organization and to examine the skills that are required for IS executives and how these skills are associated with increasing business value.

Finally, managers who implement all the phases of SISP process in agritourism SMEs can make more efficient and timely planned strategic and tactical decisions as the process provides them with updated information to analyze the external environment of the business. As a result, the environmental uncertainty is minimized as well as risk under dynamic change. Moreover, the implementation of a SISP process in agritourism SMEs provides a significant advantage for managers. In process managers' final step, they will consider whether the plan is being followed and if the goals are being achieved. If not, action is required to change the execution activities or even modify the plan itself. Another important benefit of the process is the participation of executives of various hierarchical levels. Their engagement enhances the increased usage of the process and the effectiveness in decision making. Therefore, future researchers can examine how their participation in the process can be increased. 
A drawback of this paper emerges from the fact that only one sector of business in Greece was studied. Future researchers may analyze the findings of this research and compare them with those of large corporations operating in other countries. Another limitation of this paper is that data collected from Greek SMEs were limited so authors cannot generalize the findings of this paper in other sectors. Thus, future researchers could collect more data and conduct this survey in other sectors and compare the results with those of this article. Obviously, for future studies, several procedures for data analysis should be made use of by researchers, such as validity analysis and cluster analysis used to compare the dissimilarities in SISP application amongst companies of different industries.

Author Contributions: Conceptualization, F.K.; methodology, M.K.; data collection, M.K.; writing-original draft preparation, F.K. and M.K.; writing-review and editing, F.K. and M.K.; supervision, F.K. All authors have read and agreed to the published version of the manuscript.

Funding:

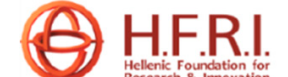

"The research work was supported by the Hellenic Foundation for Research and Innovation (HFRI) under the HFRI PhD Fellowship grant (Fellowship Number: 188)."

Conflicts of Interest: The authors declare no conflicts of interest.

\section{References}

1. Baregheh, A.; Rowley, J.; Sambrook, S.; Davies, D. Innovation in food sector SMEs. J. Small Bus. Enterp. Dev. 2012, 19, 300-321. [CrossRef]

2. Sturiale, L.; Scuderi, A. Information and Communication Technology (ICT) and Adjustment of the Marketing Strategy. In Proceedings of the 5th International Conference on Information and Communication Technologies for Sustainable Agri-production and Environment (HAICTA 2011), Skiathos, Greece, 8-11 September 2011; pp. 77-87.

3. Kamariotou, M.; Kitsios, F.; Madas, M.; Manthou, V.; Vlachopoulou, M. Strategic Decision Making and Information Management in the Agrifood Sector. In Proceedings of the 8th International Conference on Information and Communication Technologies in Agriculture, Food \& Environment, Chania, Crete, Greece, 21-24 September 2017; Salampasis, M., Bournaris, T., Eds.; Springer Series: Manhattan, NY, USA, 2019; Volume 953, pp. 97-109.

4. Kamariotou, M.; Kitsios, F.; Madas, M.; Manthou, V.; Vlachopoulou, M. Strategic Decision Support Systems for Logistics in the Agrifood Industry. In Proceedings of the 8th International Conference on Information and Communication Technologies in Agriculture, Food \& Environment, Chania, Crete, Greece, 21-24 September 2017; pp. 781-794.

5. Gold, S.; Kunz, N.; Reiner, G. Sustainable global agrifood supply chains: Exploring the barriers. J. Ind. Ecol. 2017, 21, 249-260. [CrossRef]

6. Kitsios, F.; Kamariotou, M. Decision Support Systems for Strategic Information Systems Planning: An Approach for Logistics Strategic Management. Int. J. Decis. Support Syst. 2018, 3, 207-221. [CrossRef]

7. Koutsouris, A.; Gidarakou, I.; Grava, F.; Michailidis, A. The phantom of (agri) tourism and agriculture symbiosis? A Greek case study. Tour. Manag. Perspect. 2014, 12, 94-103. [CrossRef]

8. Kachigan, S.K. Multivariate Statistical Analysis: A Conceptual Introduction, 2nd ed.; Radius Press: Santa Fe, Argentina, 1991.

9. Kitsios, F.; Kamariotou, M.; Madas, M.; Fouskas, K.; Manthou, V. Information systems strategy in SMEs: Critical factors of strategic planning in logistics. Kybernetes 2019, 49, 1197-1212. [CrossRef]

10. Kitsios, F.; Charatsari, C.; Kamariotou, M. Strategic Decision Support Systems for Short Supply Chain Development in the Agrifood Sector. Int. J. Decis. Support. Syst. 2019, 4, 115-129. [CrossRef]

11. Kitsios, F.; Kamariotou, M.; Madas, M.; Fouskas, K.; Manthou, V. Strategic Information Systems in Logistics and Supply Chain Management. In Proceedings of the 4th International Conference on Decision Support. System Technology (ICDSST2018), Heraklion, Greece, 22-25 May 2018; pp. 216-221.

12. Kuethe, T.; Morehart, M. The agricultural resource management survey: An information system for production agriculture. Agric. Financ. Rev. 2012, 72, 191-200. [CrossRef] 
13. Soeparno, H.; Perbangsa, A.S.; Pardamean, B. Best Practices of Agricultural Information System in the Context of Knowledge and Innovation. In Proceedings of the 2018 IEEE International Conference on Information Management and Technology (ICIMTech), Jakarta, Indonesia, 3-5 September 2018; pp. 1-9.

14. Giannacourou, M.; Kantaraki, M.; Christopoulou, V. The Perception of Crisis by Greek SMEs and its Impact on Managerial Practices. Procedia Soc. Behav. Sci. 2015, 175, 546-551. [CrossRef]

15. Rathnam, R.G.; Johnsen, J.; Wen, H.J. Alignment of Business Strategy and IT Strategy: A Case Study of a Fortune 50 Financial Services Company. J. Comput. Inf. Syst. 2004, 45, 1-8.

16. Siakas, K.; Naaranoja, M.; Vlachakis, S.; Siakas, E. Family businesses in the new economy: How to survive and develop in times of financial crisis. Procedia Econ. Financ. 2014, 9, 331-341. [CrossRef]

17. Vassiliadis, S.; Vassiliadis, A. The Greek family businesses and the succession problem. Procedia Econ. Financ. 2014, 9, 242-247. [CrossRef]

18. Kitsios, F.; Kamariotou, M. Strategic IT alignment: Business performance during financial crisis. In Advances in Applied Economic Research; Tsounis, N., Vlachvei, A., Eds.; Springer: New York, NY, USA, 2017; pp. 503-525.

19. Ullah, A.; Lai, R. A systematic review of business and information technology alignment. ACM Trans. Manag. Inf. Syst. 2013, 4, 1-30. [CrossRef]

20. Suh, H.; Hillegersberg, J.V.; Choi, J.; Chung, S. Effects of strategic alignment on IS success: The mediation role of IS investment in Korea. Inf. Technol. Manag. 2013, 14, 7-27. [CrossRef]

21. Kitsios, F.; Kamariotou, M. Decision Support Systems and Strategic Information Systems Planning for Strategy Implementation. In Strategic Innovative Marketing, Proceedings of the Business and Economics; Kavoura, A., Sakas, D., Tomaras, P., Eds.; Springer: New York, NY, USA, 2017; pp. 327-332.

22. Brown, I. Strategic Information Systems Planning: Comparing Espoused Beliefs with Practice. In Proceedings of the 18th European Conference on Information Systems, Pretoria, South Africa, 6-9 June 2010; pp. 1-12.

23. Brown, I.T.J. Testing and Extending Theory in Strategic Information Systems Planning Through Literature Analysis. Inf. Resour. Manag. J. 2004, 17, 20-48. [CrossRef]

24. Kamariotou, M.; Kitsios, F. An Empirical Evaluation of Strategic Information Systems Planning Phases in SMEs: Determinants of Effectiveness. In Proceedings of the 6th International Symposium and 28th National Conference on Operational Research, Thessaloniki, Greece, 8-9 June 2017; pp. 67-72.

25. Kamariotou, M.; Kitsios, F. Information Systems Phases and Firm Performance: A conceptual Framework. In Strategic Innovative Marketing. Springer Proceedings in Business and Economics; Kavoura, A., Sakas, D., Tomaras, P., Eds.; Springer: New York, NY, USA, 2017; pp. 553-560.

26. Kamariotou, M.; Kitsios, F. Strategic Information Systems Planning: SMEs Performance outcomes. In Proceedings of the 5th International Symposium and 27th National Conference on Operation Research, Athens, Greece, 9-11 June 2016; pp. 153-157.

27. Kitsios, F.; Kamariotou, M. Decision Support Systems and Strategic Planning: Information Technology and SMEs Performance. Int. J. Decis. Support Syst. 2018, 3, 53-70. [CrossRef]

28. Maharaj, S.; Brown, I. The impact of shared domain knowledge on strategic information systems planning and alignment: Original research. S. Afr. J. Inf. Manag. 2015, 17, 1-12. [CrossRef]

29. Mentzas, G. Implementing an IS Strategy- A Team Approach. Long Range Plan. 1997, 30, 84-95. [CrossRef]

30. Mirchandani, D.A.; Lederer, A.L. "Less is More:" Information Systems Planning in an Uncertain Environment. Inf. Syst. Manag. 2014, 29, 13-25. [CrossRef]

31. Newkirk, H.E.; Lederer, A.L.; Srinivasan, C. Strategic information systems planning: Too little or too much? J. Strateg. Inf. Syst. 2003, 12, 201-228. [CrossRef]

32. Newkirk, H.E.; Lederer, A.L. The effectiveness of strategic information systems planning under environmental uncertainty. Inf. Manag. 2006, 43, 481-501. [CrossRef]

33. Kamariotou, M.; Kitsios, F. Critical Factors of Strategic Information Systems Planning Phases in SMEs. In Information Systems; EMCIS 2018; Springer LNBIP 341; Themistocleous, M., Rupino da Cunha, P., Eds.; Springer Nature: Cham, Switzerland, 2019; pp. 503-517.

34. Kamariotou, M.; Kitsios, F. Strategic Information Systems Planning. In Encyclopedia of Information Science and Technology; Mehdi, K.-P., Ed.; IGI Global Publishing: Hershey, PA, USA, 2018; Chapter 78; pp. 912-922.

35. Lederer, A.L.; Sethi, V. Key prescriptions for strategic information systems planning. J. Manag. Inf. Syst. 1996, 13, 35-62. [CrossRef]

36. Newkirk, H.E.; Lederer, A.L.; Johnson, A.M. Rapid business and IT change: Drivers for strategic information systems planning? Eur. J. Inf. Syst. 2008, 17, 198-218. [CrossRef] 
37. Pai, J.C. An empirical study of the relationship between knowledge sharing and IS/IT strategic planning (ISSP). Manag. Decis. 2006, 44, 105-122. [CrossRef]

38. Zubovic, A.; Pita, Z.; Khan, S. A Framework for Investigating the Impact of Information Systems Capability on Strategic Information Systems Planning Outcomes. In Proceedings of the 18th Pacific Asia Conference on Information Systems, Chengdu, China, 24-25 June 2014; pp. 1-12.

39. Kitsios, F.; Kamariotou, M. Strategic IT Alignment and Business Performance in SMEs: An Empirical Investigation. In Business Information Systems Workshops; Springer LNBIP 373; Abramowicz, W., Corchuelo, R., Eds.; Springer Nature: Cham, Switzerland, 2019; Volume 373, pp. 113-123.

40. Kamariotou, M.; Kitsios, F. Evaluating IT alignment and performance in SMEs using Multivariate Regression Analysis. In Proceedings of the 19th International Conference on Electronic Business (ICEB), Newcastle, UK, 8-12 December 2019; pp. 222-230.

41. Kitsios, F.; Kamariotou, M. Information Systems Strategy and Strategy-as-Practice: Planning Evaluation in SMEs. In Proceedings of the Americas Conference on Information Systems (AMCIS2019), Cancun, Mexico, 15-17 August 2019; pp. 1-10.

42. Kamariotou, M.; Kitsios, F. Strategic Planning and Information Systems Success: Evaluation in Greek SMEs. In Proceedings of the 21st IEEE Conference on Business Informatics (CBI2019), Moscow, Russia, 15-17 July 2019; pp. 204-211.

43. Peppard, J.; Ward, J. Beyond strategic information systems: Towards an IS capability. J. Strateg. Inf. Syst. 2004, 13, 167-194. [CrossRef]

44. Kamariotou, M.; Kitsios, F. Information Systems Planning and Success in SMEs: Strategizing for IS. In BIS 2019; Springer LNBIP 353; Abramowicz, W., Corchuelo, R., Eds.; Springer Nature: Cham, Switzerland, 2019; Chapter 31; pp. 397-406.

45. Kamariotou, M.; Kitsios, F. Information Systems Planning and Business Strategy: Implications for Planning Effectiveness. In Proceedings of the 8th International Symposium \& 30th National Conference on Operational Research, Patras, Greece, 16-18 May 2019; pp. 58-62.

46. Kitsios, F.; Kamariotou, M. Business Strategy Modelling based on Enterprise Architecture: A State of the Art Review. Bus. Process Manag. J. 2019, 25, 606-624. [CrossRef]

47. Kitsios, F.; Kamariotou, M. Decision Support Systems and Business Strategy: A conceptual framework for Strategic Information Systems Planning. In Proceedings of the 6th IEEE International Conference on IT Convergence and Security (ICITCS2016), Prague, Czech Republic, 26-29 September 2016; pp. 149-153.

48. Merali, Y.; Papadopoulos, T.; Nadkarni, T. Information systems strategy: Past, present, future? J. Strateg. Inf. Syst. 2012, 21, 125-153. [CrossRef]

49. Spinelli, R.; Dyerson, R.; Harindranath, G. IT readiness in small firms. J. Small Bus. Enterp. Dev. 2013, 20, 807-823. [CrossRef]

50. Bourletidis, K.; Triantafyllopoulos, Y. SMEs survival in time of crisis: Strategies, tactics and commercial success stories. Procedia Soc. Behav. Sci. 2014, 148, 639-644. [CrossRef]

(C) 2020 by the authors. Licensee MDPI, Basel, Switzerland. This article is an open access article distributed under the terms and conditions of the Creative Commons Attribution (CC BY) license (http://creativecommons.org/licenses/by/4.0/). 